\title{
Change in the starch granules of tuber parts of "Kangba" and "Krenglè" (Dioscorea cayenenesis-rotundata complex) during post-harvest storage
}

\author{
Soumaïla DABONNE ${ }^{1}$, Kouakou Martin DJE ${ }^{1}$, Fabrice Achille TETCHI ${ }^{2 *}$ and \\ Lucien Patrice KOUAME ${ }^{1}$ \\ ${ }^{1}$ Laboratory of Biochemistry and Food Technology, University of Abobo Adjamé, UFR/STA, 02 BP 801 \\ Abidjan 02 (Côte d'Ivoire). \\ ${ }^{2}$ Laboratory of Food Biochemistry and Tropical Products Technology; University of Abobo Adjamé, \\ UFR/STA, 02 BP 801 Abidjan 02 (Côte d'Ivoire). \\ *Corresponding author, E-mail: tetchifa@yahoo.fr
}

\begin{abstract}
The aim of the study was to monitor variations of starch granules in two varieties of yam tuber parts during post-harvest storage. The morphological properties of yam part starches isolated from two cultivars ("Kangba" and "Krenglè") belonging to Dioscorea cayenensis-rotundata complex species were evaluated. The shapes of starch granules from yam tuber parts of each cultivar were similar and these shapes were the same from one cultivar to another. They appeared polyhedral, ovo-triangular, oval and some oblong. As for the granules' size, it appeared significant $(\mathrm{P} \leq 0.05)$ and ranging from $5.8 \mu \mathrm{m}$ to $61.8 \mu \mathrm{m}$ in the proximal tuber parts and $5.4 \mu \mathrm{m}$ to $53.8 \mu \mathrm{m}$ in distal tuber parts during the post-harvest storage. The proximal tuber parts had the highest size of granules $(\varnothing=26.8-36.6 \mu \mathrm{m})$. Moreover, the different tuber parts of "Kangba" cultivar presented the highest size of starch granules $(\varnothing=27.5-36.3 \mu \mathrm{m})$.

(C) 2010 International Formulae Group. All rights reserved.
\end{abstract}

Keywords: Yam, tuber part, granules, starch, morphology, post-harvest storage

\section{INTRODUCTION}

The roots and tubers used as staple food mainly in Africa are grown in many parts of the world such as Asia, Latin American and the Caribbean (Charles et al., 2008). They contain $70-80 \%$ water, $16-24 \%$ starch and trace quantities $(<4 \%)$ of proteins and lipids (Hoover, 2001). The roots and tubers namely potato, cassava, sweet potato, taro and yam (Dioscorea spp) constitute an important potential starch reserve (Drogba and Amani, 2007). Among them, the Dioscorea cayenensis-rotundata complex species ("Kangba" and "Krenglè" cultivars) is one of the most cultivated and consumed yams in the centre of Côte d'Ivoire (Doumbia et al., 2006). Being the main caloric sources for people in many countries, starch is in high demand. It is also an excellent ingredient in food and non food industries (such as paper, plastic, adhesive, textile and pharmaceutical industries) (Wickramasinghe et al., 2009). The morphological characteristics of yam starch were determined on the whole yam tubers. However, no study has so far been carried out on morphological characteristics of the native starches of the yam tuber parts (proximal, median and distal) and during the post-harvest storage. Thus, intensive research and product 
development is needed to exploit tuber and root starches (Hoover, 2001).

This work was intended to evaluate the effect of storage time on starch granule shape and size from different parts of yam, in order to provide suggestions to improve the use of these starches in the food industry.

\section{MATERIALS AND METHODS}

\section{Raw materials}

Yam (Dioscorea cayenensis-rotundata complex species) was harvested in the fields of villages named Douibo, Bomizambo and Koubi in Tiébissou (centre of Côte d'Ivoire). The most cultivated and consumed cultivars ("Kangba" and "Krenglè") were selected for this study. Tubers of $44.07 \pm 4.46 \mathrm{~cm}$ long were stored for six months in a well-ventilated store in which the temperature and the relative humidity rate were $26.56 \pm 3{ }^{\circ} \mathrm{C}$ and $82 \pm 5 \%$ respectively.

\section{Starch isolation}

Yam starches were extracted according to the procedure described by Amani et al. (2002). Four yam tubers of each cultivar were randomly picked every two (2) months of storage during six (6) months. These tubers were cut up into three equal parts to obtain three groups composed of proximal parts (head of tuber), median parts and distal parts (tail of tuber). One kilogram (1 kg) from each group was weighed, washed and peeled. After peeling, they were cut up into small slices $(4 \times 4 \mathrm{~cm})$ with stainless steel knife and steeped in distilled water containing $0.1 \%$ (w/v) sodium metabisulphite. The slices were ground in a grinder (Moulinex, Lyon-France) and the paste recovered in $4 \%(\mathrm{w} / \mathrm{v})$ sodium chloride solution to separate proteins from the starch during $24 \mathrm{~h}$ at $25 \pm 1{ }^{\circ} \mathrm{C}$. The slurry was sieved successively through $750 \mu \mathrm{m}, 150$ $\mu \mathrm{m}$ and $100 \mu \mathrm{m}$ sieves. Then, the starches were alternatively decanted and washed at least four times with distilled water. The starch suspensions were oven-dried at $45{ }^{\circ} \mathrm{C}$ for $48 \mathrm{~h}$ [Mettenter (MMM) Venticell (BrnoCzech republic)]. The dry products were ground, quantified and then stored for analyses.

\section{Light microscopy}

Light microscopy was employed to characterise native starches with respect to appearance, shape and size of granules (Sangeetha and Rai, 2006).

The shape of the native starch granules was observed under the optical microscope (CETI, Kontich-antwerp-Belgium) fitted with camera (Sony, Tokyo-Japan). It was connected to a computer and a screen (JVCParis-France). The shape of native starch granules was defined by the coloration of starch granules with lugols $(0.2 \mathrm{~g}$ iodine in $2 \%$ KI solution). The size of the native starch granules in suspension was measured on a microscopic scale with Kappa Software.

\section{Frequency distributions of the average diameter of starch granules}

The distributions of the average diameter of starch granules were obtained with a total of 500 granules (Drogba and Amani, 2007). They were made according to the rule of Sturge (Scherrer, 1984) and translated through the histograms.

\section{Statistical analysis}

The average values and standard deviations of starch granule size were reported. Analysis of variance (ANOVA) was performed as part of the data analyses with STATISTICA 7 software (Statsoft Inc, TulsaUSA Headquarters) and XLSTAT-Pro 7.5.2 software (Addinsoft Sarl, Paris-France). The significant differences were defined at 0.05 level using the Duncan's test. The use of Sturge's rule enabled to determine the classes and associated amplitudes. 


\section{RESULTS}

\section{Morphological characteristics}

The granular morphological characteristics of the native starch granules from different tuber parts of "Kangba" and "Krenglè" cultivars during the post-harvest storage are shown in Figures 1 and 2 respectively, and the physical characteristics in Table 1. This study showed the morphological variability of native starch granules from proximal, median and distal part for each cultivar. However, the starch granule shapes did not vary during the postharvest storage up to 6 months. They appeared polyhedral, ovo-triangular, oval and some oblong. The analysis of variance revealed that the main effects and their interaction appeared significant at 0.05 level. There was significant variation at 0.05 level between the starch granule size from the different tuber parts of each cultivar and also between the starch granule size from two cultivars during the post-harvest storage. Indeed, the average diameters for the starch granules from "Kangba" cultivar varied from $36.3 \mu \mathrm{m}$ to $32.1 \mu \mathrm{m}, 34.0 \mu \mathrm{m}$ to $30.9 \mu \mathrm{m}$ and $30.7 \mu \mathrm{m}$ to $27.5 \mu \mathrm{m}$ for proximal, median and distal parts respectively (Table 1). As far as the "Krenglè" cultivar is concerned, the size of starch granules ranged from $36.6 \mu \mathrm{m}$ to $26.8 \mu \mathrm{m}$; $34.8 \mu \mathrm{m}$ to $26.5 \mu \mathrm{m}$ and $27.5 \mu \mathrm{m}$ to $25.5 \mu \mathrm{m}$ for proximal, median and distal parts respectively.

\section{Granule size distributions}

The starch granule size from different tuber parts is obtained by calculating the average diameter between the lengths of the long axis and the short axis of the granule according to Drogba and Amani (2007). Indeed, the distributions of the starch granule size from the different tuber parts of "Kangba" and "Krenglè" cultivars are shown in Figures 3-10. The intervals of size distribution, the mode of starch granule size distribution and the average diameter are summarised in Table 1. The distribution of native starch granules from studied yam tuber parts was asymmetric and variable (Figures 3-10). In fact, the starch from yam tuber proximal part had the greatest interval of distribution and the yam tuber distal part had the smallest interval of distribution (Figures 3-10). Besides, the starches of "Krenglè" cultivar presented the smallest interval of distribution which ranged from $5.8 \mu \mathrm{m}$ to $58 \mu \mathrm{m}$. Concerning the mode, the starches of yam tuber proximal parts had the largest mode and those of the yam tuber distal part had the smallest mode which ranged from $26.6 \mu \mathrm{m}$ to $37.8 \mu \mathrm{m}$ and $24.4 \mu \mathrm{m}$ to $31.9 \mu \mathrm{m}$ respectively during the postharvest storage. Otherwise, for facilitating the comparison of frequency distribution of starch granules during the post-harvest storage, we used the box plots (Figure 11) (Cleveland, 1993). It provides an excellent visual summary of many important aspects of a distribution and summarises the five following statistical measures: minimum, maximum, first quartile, median and third quartile. The first quartile representing the lower edge of the rectangular box is the smallest average diameter so that $25 \%$ of the average diameters of starch granules are below it. The third quartile defining the upper edge of the rectangular box is the smallest average diameter so that $75 \%$ of the average diameters of starch granules are below it. As for the median, it is represented by the small square in the center of the rectangular box. The third quartile that was more representative decreased during the post-harvest storage. The highest values observed were those of the beginning storage (month 0 ) for all tuber parts and the smallest values were those of the end of storage (month 6). The highest values of third quartile were shown in the proximal parts of the different cultivars and the smallest values in the distal parts. 


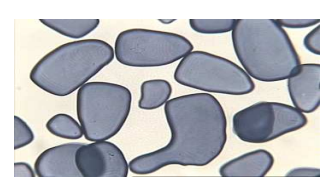

(PP 0)

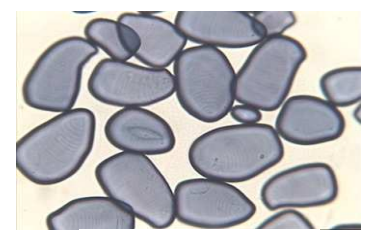

(PP 2)

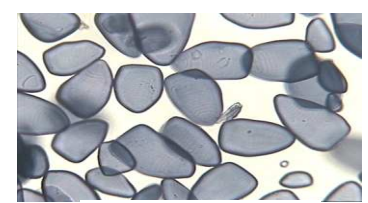

(PP 4)

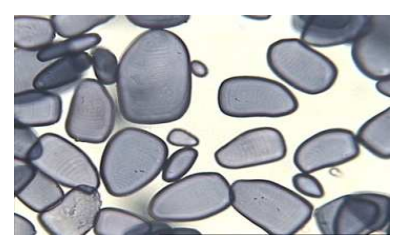

(PP 6)

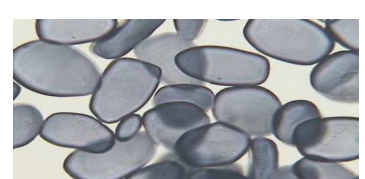

(MP 0)

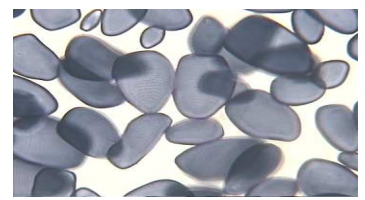

(MP 2)

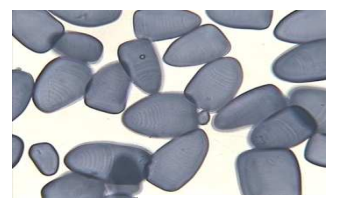

(MP 4)

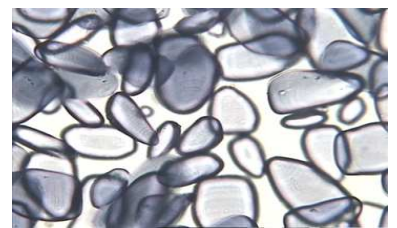

(MP 6)

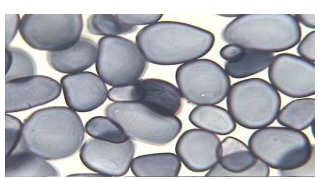

(DP 0)

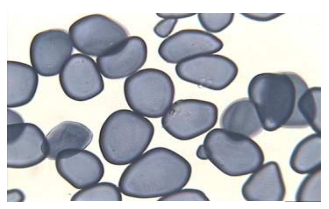

(DP 2)

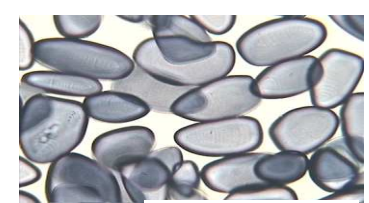

(DP 4)

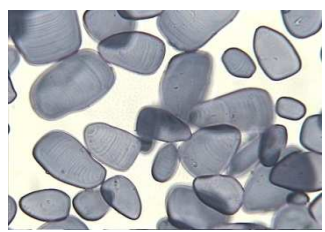

(DP 6)

Figure 1: Light microscopy of the native starch granules of "Kangba" cultivar tuber part from month 0 to month 6 (x400). PP: proximal part; MP: median part; DP: distal part. 0, 2, 4 and 6: storage time (months)

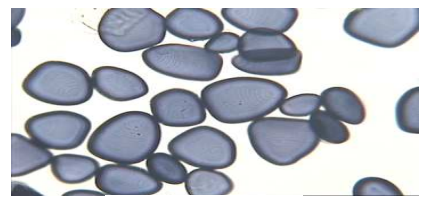

(PP 0)

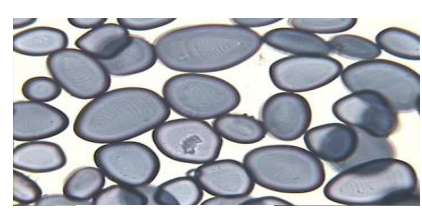

(PP 2)

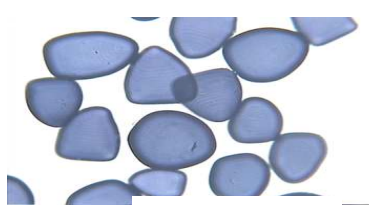

(MP 0)

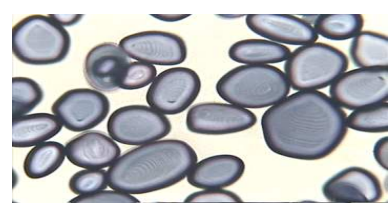

(MP 2)

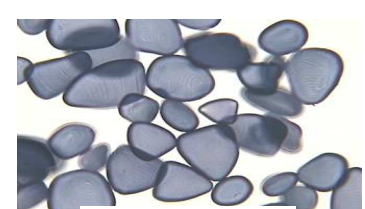

(DP 0)

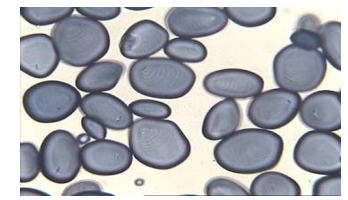

(DP 2) 


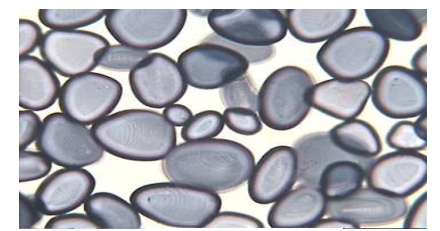

(PP 4)

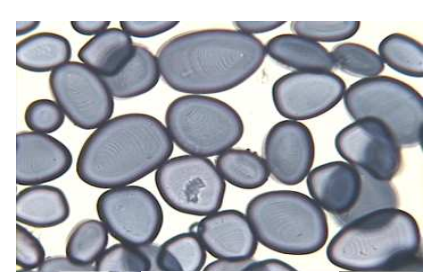

(PP 6)

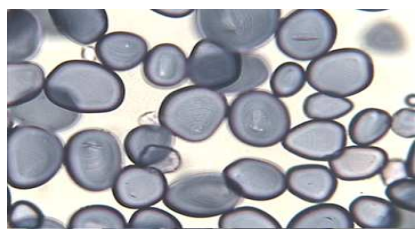

(MP 4)

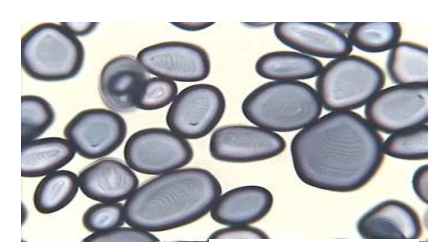

(MP 6 )

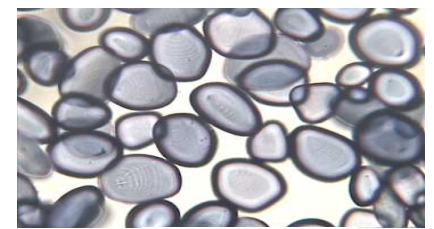

(DP 4)

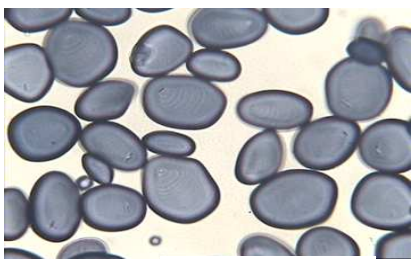

(DP 6)

Figure 2: Light microscopy of the native starch granules of "Krenglè" cultivar tuber part from month 0 to month 6 (x400). PP: proximal part; MP: median part; DP: distal part; $\mathbf{0 , 2 , 4}$ and 6: storage time (months).

\section{DISCUSSION}

The effects of storage time on the starch granule size have rarely been examined, although several previous studies have focused on starch granules of yam whole tubers. The starch granule shapes observed in the proximal, median and distal parts were similar during the storage time. These shapes agreed with those recorded by several other authors, (Delpeuch et al., 1978; Gallant et al., 1982; Trèche, 1989; Hoover, 2001; Moorty, 2002; Lindeboom et al., 2004). These authors reported the ovotriangular, oblong, oval, polyhedral and ellipsoid shapes in the whole tubers of Dioscorea cayenensis-rotundata complex. Indeed, the morphological characters of the native starch granule of the yam tubers could be attributed to the several factors of genetic nature (Dégras, 1986). Contrary to the shape, the average diameter size of the starch granules varied significantly $(\mathrm{P} \leq 0.05)$ from one tuber part to another, with the highest values in the proximal parts and the lowest values in the distal parts whatever the variety was. The range values of the average diameter size for the yam different tuber parts were similar to those of Hoover (2001), who reported the average diameters of starch granules ranging from $10 \mu \mathrm{m}$ to $70 \mu \mathrm{m}$ for Dioscorea cayenensis-rotundata complex. These values were also similar to those of Tetchi et al. (2007) who reported $32 \mu \mathrm{m}$ as the average diameter of "Kponan" cultivar (Dioscorea cayenensis-rotundata complex). However, all the results were slightly higher than the reports of De Vizcarrondo et al. (2004) which indicated the average diameter size of starch granules varying from $21.8 \mu \mathrm{m}$ to $35.0 \mu \mathrm{m}$ for Dioscorea bulbifera. Compared to other roots and tuber starches, the obtained results were also higher than those reported by Amani et al. (2004) who found that the average diameter size of starch granules were ranging from $6.4 \mu \mathrm{m}$ to 38.5 $\mu \mathrm{m}$ for Zingiber officinale roscoe. The variation in size and shape of starch granules may be due to the biological origin (Svegmark and Hermansson, 1993). The morphology of starch granules depends on biochemistry of the chloroplast or amyloplast, as well as physiology of the plant (Badenhuizen, 1969). 

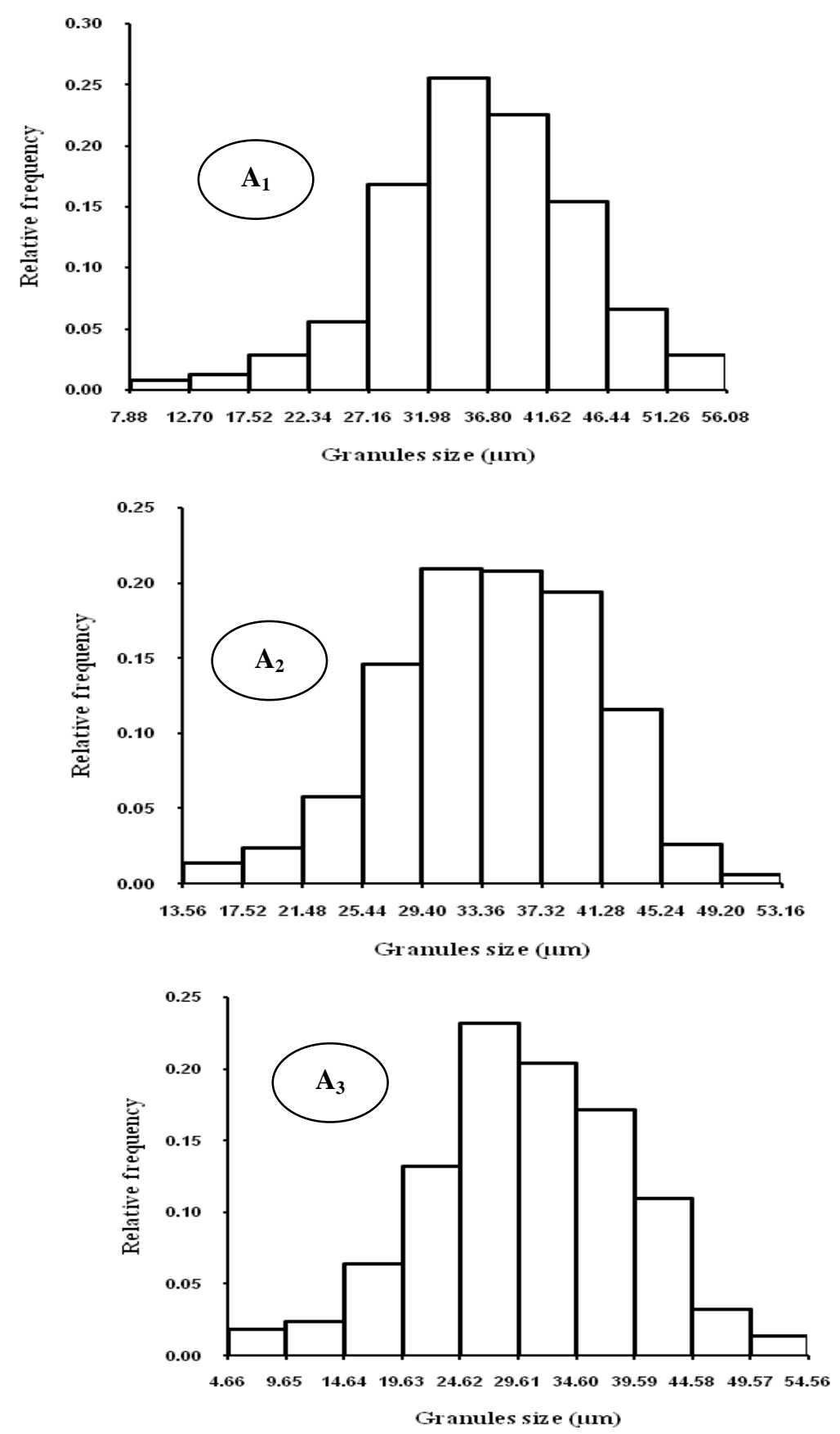

Figure 3: Frequency distribution of native starch granule average diameters of proximal $\left(\mathrm{A}_{1}\right)$, median $\left(\mathrm{A}_{2}\right)$ and distal $\left(\mathrm{A}_{3}\right)$ yam tuber parts of the "Kangba" cultivar (D.c.r. complex) at the month 0. 

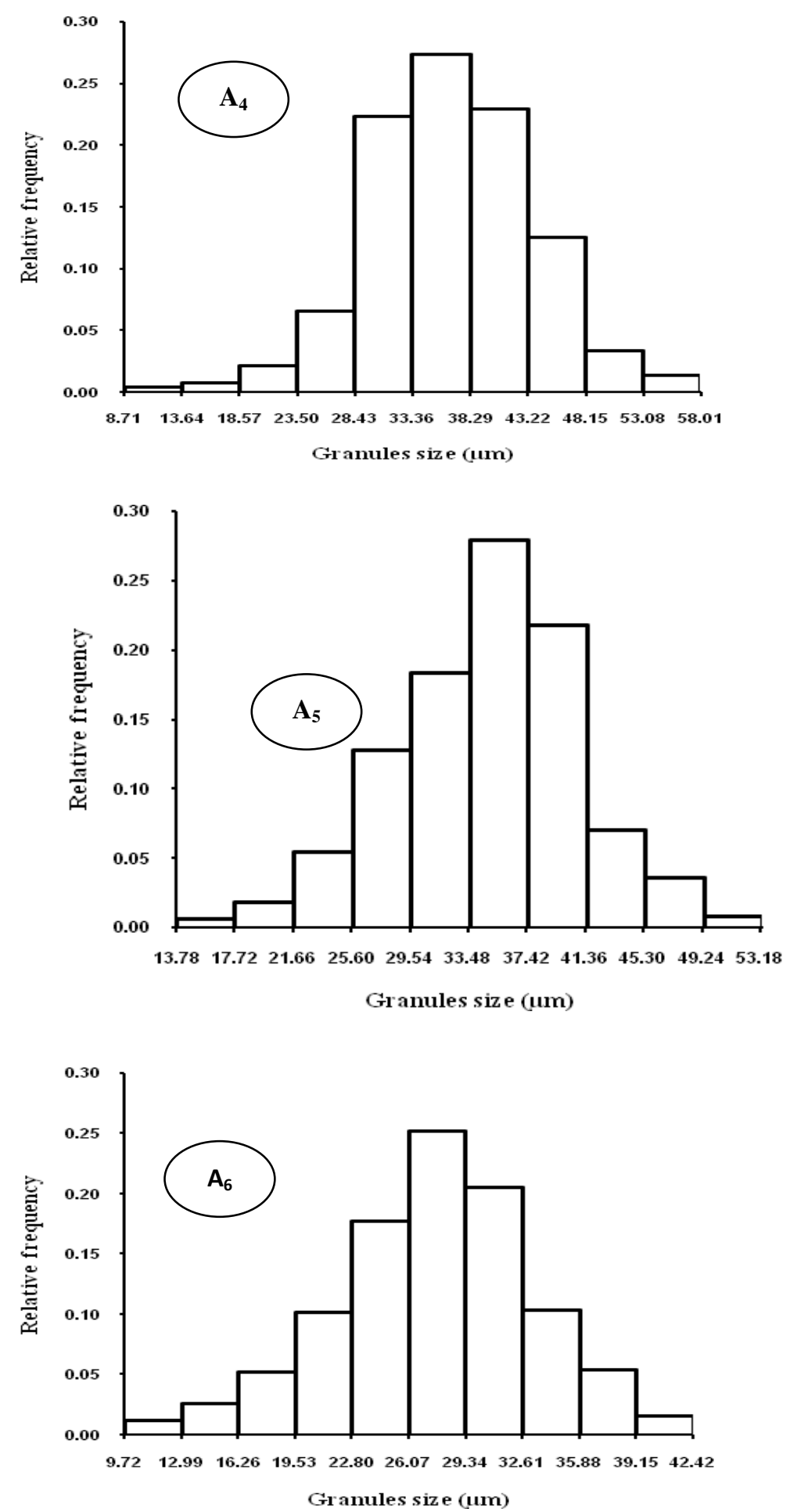

Figure 4: Frequency distribution of native starch granule average diameters of proximal $\left(\mathrm{A}_{4}\right)$, median $\left(\mathrm{A}_{5}\right)$ and distal $\left(\mathrm{A}_{6}\right)$ yam tuber parts of the "Krenglè" cultivar (D.c.r. complex) at the month 0 . 

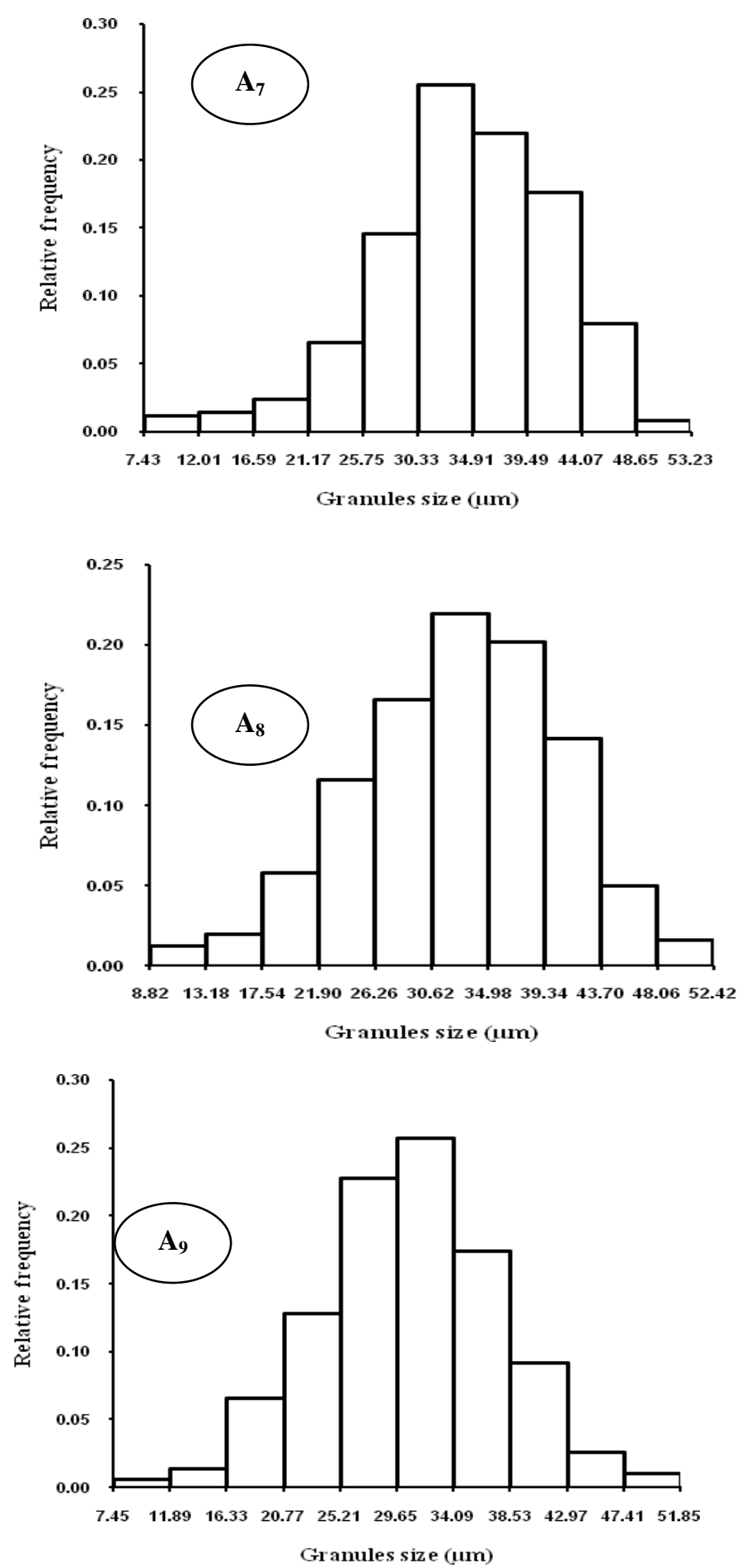

Figure 5: Frequency distribution of native starch granule average diameters of proximal $\left(\mathrm{A}_{7}\right)$, median $\left(\mathrm{A}_{8}\right)$ and distal $\left(\mathrm{A}_{9}\right)$ yam tuber parts of the "Kangba" cultivar (D.c.r. complex) at the month 2. 

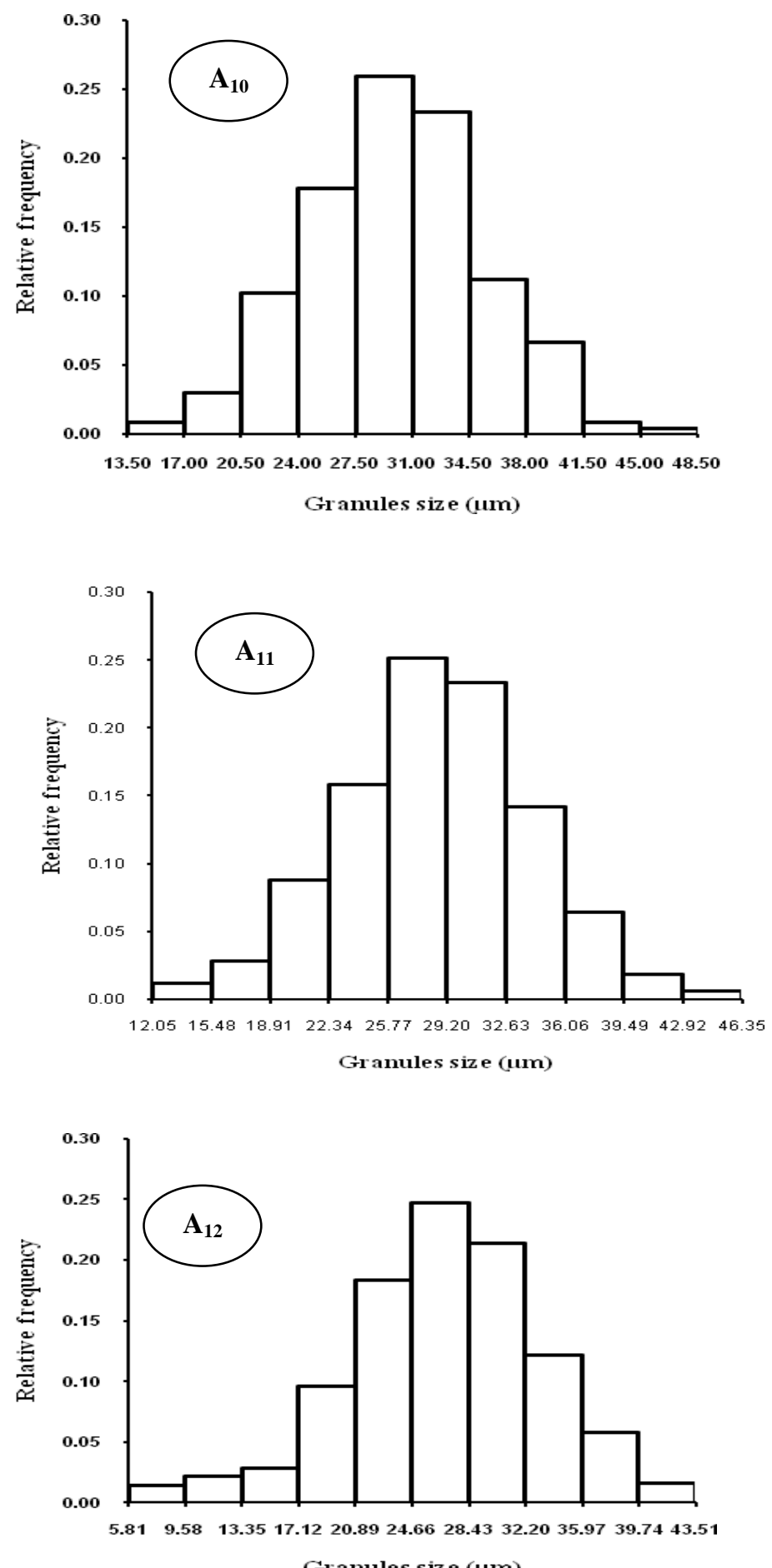

Figure 6: Frequency distribution of native starch granule average diameters of proximal $\left(\mathrm{A}_{10}\right)$, median $\left(\mathrm{A}_{11}\right)$ and distal $\left(\mathrm{A}_{12}\right)$ yam tuber parts of the "Krenglè" cultivar (D.c.r. complex) at the month 2. 

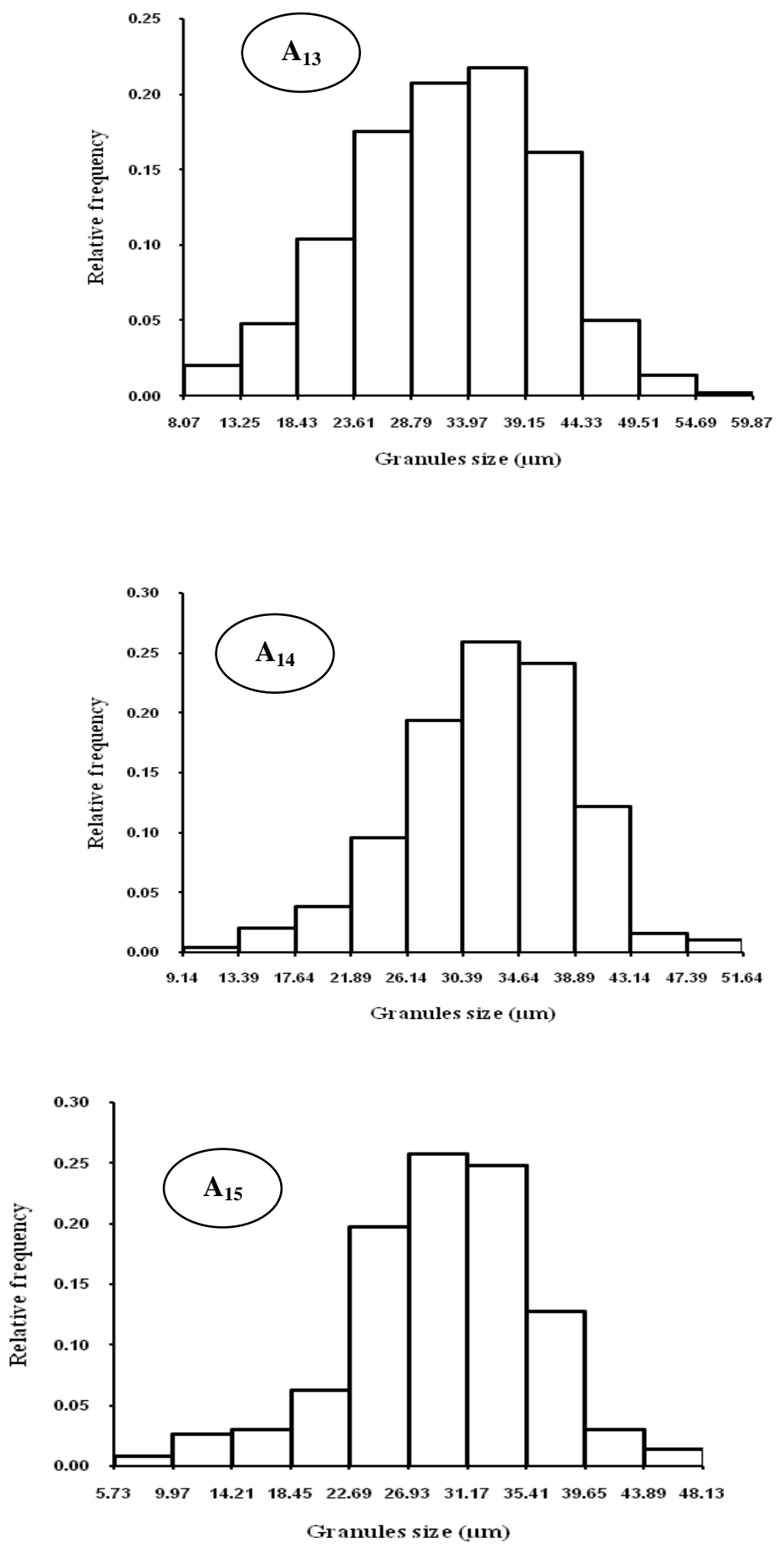

Figure 7: Frequency distribution of native starch granule average diameters of proximal $\left(\mathrm{A}_{13}\right)$, median $\left(\mathrm{A}_{14}\right)$ and distal $\left(\mathrm{A}_{15}\right)$ yam tuber parts of the "Kangba" cultivar (D.c.r. complex) at the month 4. 

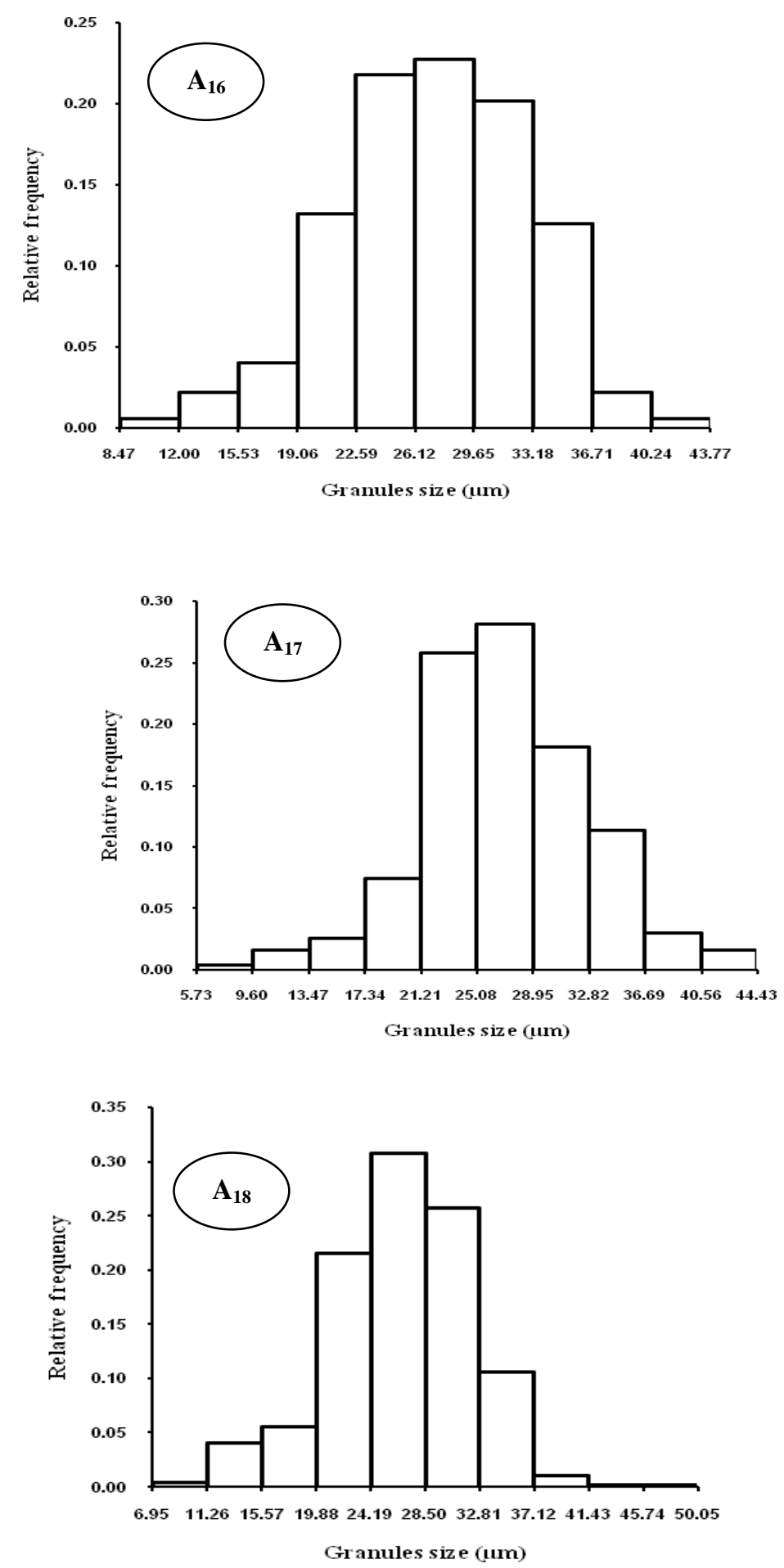

Figure 8: Frequency distribution of native starch granule average diameters of proximal $\left(\mathrm{A}_{16}\right)$, median $\left(\mathrm{A}_{17}\right)$ and distal $\left(\mathrm{A}_{18}\right)$ yam tuber parts of the "Krenglè" cultivar (D.c.r. complex) at the month 4 . 

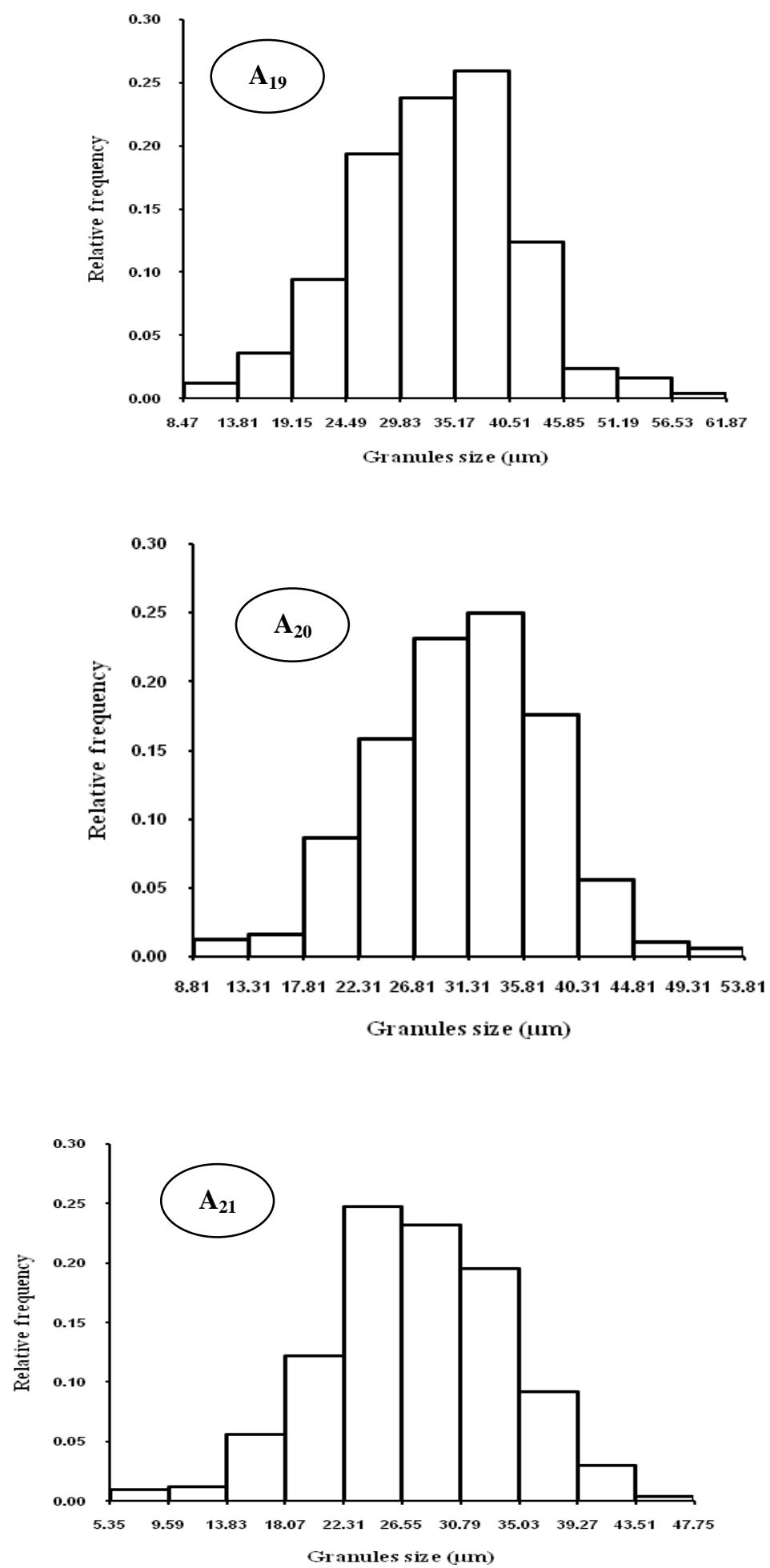

Figure 9: Frequency distribution of native starch granule average diameters of proximal $\left(\mathrm{A}_{19}\right)$, median $\left(\mathrm{A}_{20}\right)$ and distal $\left(\mathrm{A}_{21}\right)$ yam tuber parts of the "Kangba" cultivar (D.c.r. complex) at the month 6. 

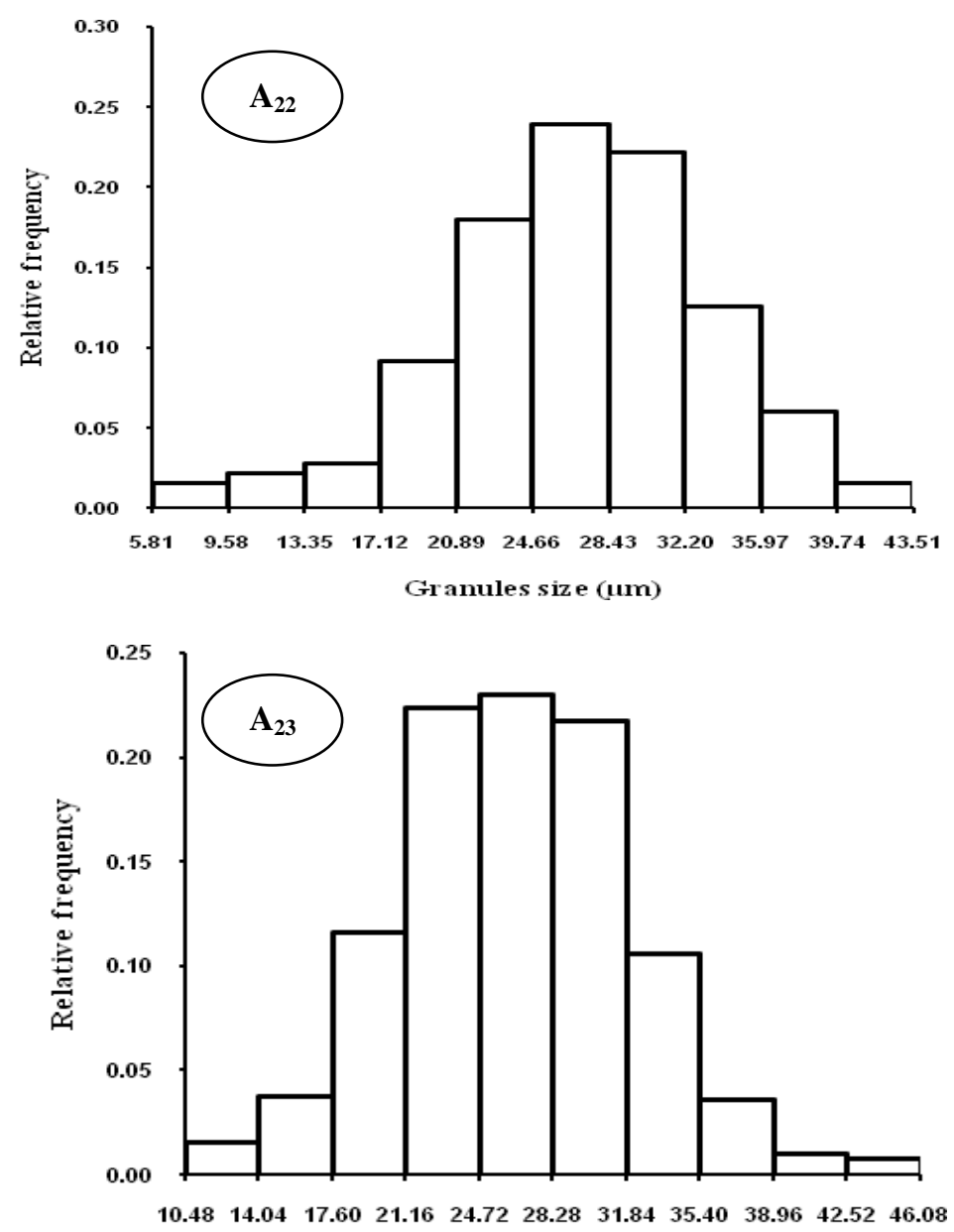

Granules size (um)

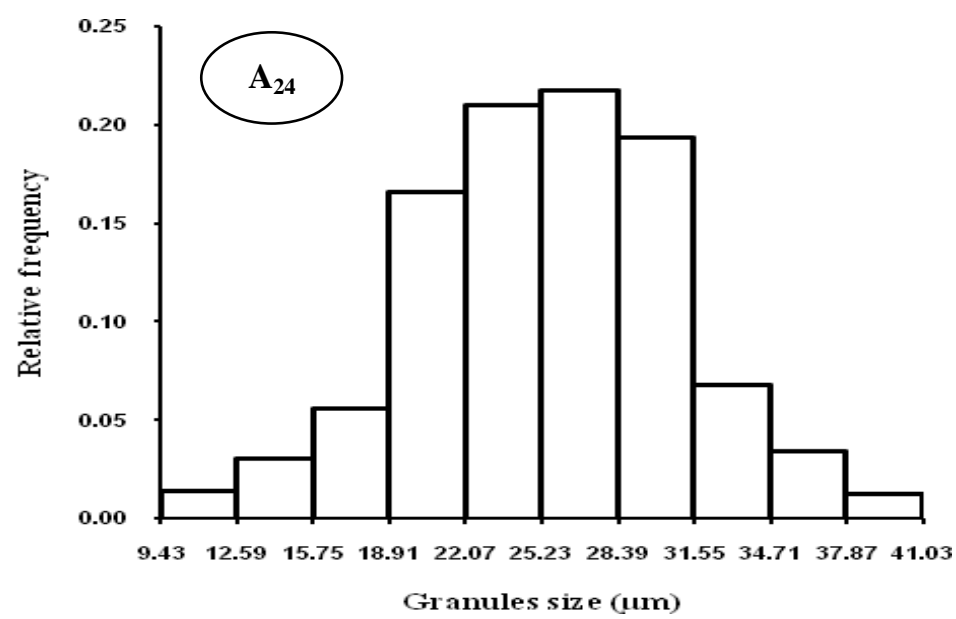

Figure 10: Frequency distribution of native starch granule average diameters of proximal $\left(\mathrm{A}_{19}\right)$, median $\left(\mathrm{A}_{20}\right)$ and distal $\left(\mathrm{A}_{21}\right)$ yam tuber parts of the "Krenglè" cultivar (D.c.r. complex) at the month 6 . 

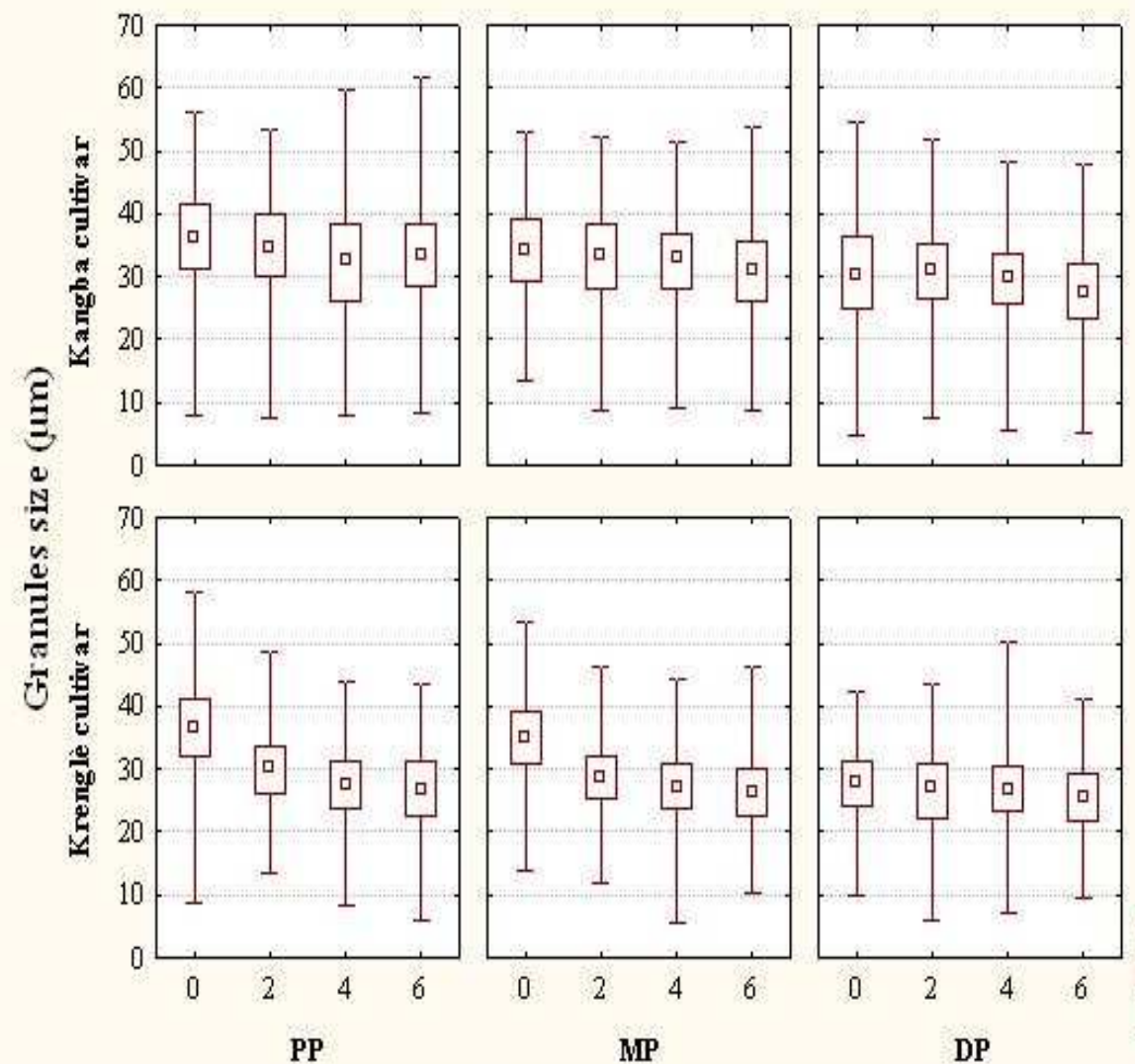

ㅁ Median

$725 \% 75 \%$

Tuber parts at different storage time

Figure 11: Evolution of native starch granule diameter of different parts of "Kangba" and "Krenglè" cultivars during the postharvest storage.

The heterogeneity of the starch granule size in the yam tuber with largest average diameter in the proximal parts may be due to the age of the different parts. Indeed, the proximal part formerly formed would possess more aged and evolved tissues. The distal parts would present slight aged and evolved tissues and this would be explained by the presence of more small starch granule size in the distal part (Dégras, 1994). The analysis of variance revealed significant differences $(\mathrm{P} \leq 0.05)$ between the average diameters of the starch granules of the month 0 and those of the month 6 . The differences of the average size recorded from the month 2 to the month 4 were not significant at 0.05 level. The size of the starch granules would be a deciding parameter in the substantial interpretation of the starch properties (Deang and Del Rosario,
1999). Otherwise, the box plot generally permitted to confirm the symmetrical unimodality of the frequency distributions of the average diameter size of different tuber part starches during the post-harvest storage. This would indicate that the distribution function of the starch granules of proximal, median and distal parts follows the normal law. These results are similar to those reported by Trèche (1989) and Drogba and Amani (2007) who showed the unimodality of yam tuber starch granule distribution. The box plot diagrams revealed that the starch granule size of yam's different tuber parts decreased during the post-harvest storage. It was shown by the variation of the third quartile during the post-harvest storage. The third quartile was 
S. DABONNE et al. / Int. J. Biol. Chem. Sci. 4(5): 1373-1389, 2010

Table 1: Physical characteristics of starch granules from different parts of some yams tubers during post-harvest storage.

\begin{tabular}{|c|c|c|c|c|c|c|c|c|c|}
\hline \multirow[b]{3}{*}{ Cultivars } & \multirow[b]{3}{*}{$\begin{array}{l}\text { tuber } \\
\text { Parts }\end{array}$} & \multicolumn{8}{|c|}{ Storage time } \\
\hline & & \multicolumn{4}{|c|}{ Month 0} & \multicolumn{4}{|c|}{ Month 2} \\
\hline & & $\begin{array}{c}\text { Granules } \\
\text { Shape }\end{array}$ & $\begin{array}{c}\text { Interval } \\
\text { granules size } \\
(\mu \mathrm{m})\end{array}$ & $\begin{array}{l}\text { Mode } \\
(\mu \mathrm{m})\end{array}$ & $\begin{array}{c}\text { Average } \\
\text { diameter } \\
(\mu \mathrm{m})\end{array}$ & $\begin{array}{c}\text { Granules } \\
\text { Shape }\end{array}$ & $\begin{array}{c}\text { Interval } \\
\text { granules size } \\
(\mu \mathrm{m})\end{array}$ & $\begin{array}{l}\text { Mode } \\
(\mu \mathrm{m})\end{array}$ & $\begin{array}{c}\text { Average } \\
\text { diameter } \\
(\mu \mathrm{m})\end{array}$ \\
\hline \multirow{3}{*}{ Kangba } & $\mathbf{P P}$ & $\begin{array}{c}\text { Polyhedral } \\
\text { Ovotriangular } \\
\text { Oval }\end{array}$ & $7.9-56.1$ & 34.4 & $36.3 \pm 7.9$ & $\begin{array}{c}\text { Polyedral } \\
\text { Ovotriangular } \\
\text { Oval }\end{array}$ & $7.4-53.2$ & 32.6 & $34.4 \pm 7.6$ \\
\hline & PM & idem & $13.6-53.1$ & 31.4 & $34.0 \pm 6.7$ & idem & $8.8-52.4$ & 32.8 & $32.8 \pm 7.8$ \\
\hline & PD & idem & $4.7-54.6$ & 27.1 & $30.7 \pm 7.1$ & idem & $7.5-51.9$ & 31.9 & $30,4 \pm 8,8$ \\
\hline \multirow{4}{*}{ Krenglè } & PP & idem & $8.7-57.9$ & 35.8 & $36.6 \pm 7.0$ & idem & $13.5-48.5$ & 29.3 & $30.0 \pm 5.4$ \\
\hline & PM & idem & $13.8-53.2$ & 35.5 & $34.8 \pm 6.2$ & idem & $12.1-46.4$ & 27.5 & $28.6 \pm 5.5$ \\
\hline & PD & idem & $9.7-42.4$ & 27.7 & $27.5 \pm 5.8$ & idem & $5.8-43.5$ & 26.6 & $26.7 \pm 6.4$ \\
\hline & & \multicolumn{4}{|c|}{ Month 4} & \multicolumn{4}{|c|}{ Month 6} \\
\hline Cultivars & $\begin{array}{l}\text { tuber } \\
\text { Parts }\end{array}$ & $\begin{array}{c}\text { Granules } \\
\text { Shape }\end{array}$ & $\begin{array}{c}\text { Interval } \\
\text { granules size } \\
(\mu \mathrm{m})\end{array}$ & $\begin{array}{l}\text { Mode } \\
(\mu \mathrm{m})\end{array}$ & $\begin{array}{c}\text { Average } \\
\text { diameter } \\
(\mu \mathrm{m}\end{array}$ & $\begin{array}{c}\text { Granules } \\
\text { Shape }\end{array}$ & $\begin{array}{c}\text { Interval } \\
\text { granules size } \\
(\mu \mathrm{m})\end{array}$ & $\begin{array}{c}\text { Mode } \\
(\mu \mathrm{m})\end{array}$ & $\begin{array}{c}\text { Average } \\
\text { diameter } \\
(\mu \mathrm{m}\end{array}$ \\
\hline \multirow{6}{*}{ Kangba } & $\mathbf{P P}$ & $\begin{array}{c}\text { Polyhedral } \\
\text { Ovotriangular } \\
\text { Oval }\end{array}$ & $8.1-59.9$ & 36.6 & $33.1 \pm 8.1$ & $\begin{array}{c}\text { Polyhedral } \\
\text { Ovotriangular } \\
\text { Oval }\end{array}$ & $8.5-61.8$ & 37.8 & $32.1 \pm 8.7$ \\
\hline & PM & idem & $9.1-51.6$ & 32.5 & $32.4 \pm 6.5$ & idem & $8.8-53.8$ & 33.5 & $30.9 \pm 6.9$ \\
\hline & PD & idem & $5.7-48.1$ & 29.1 & $29.4 \pm 6.7$ & idem & $5.4-47.7$ & 24.4 & $27.5 \pm 6.6$ \\
\hline & PP & idem & $8.5-43.8$ & 27.9 & $27.3 \pm 5.6$ & idem & $5.8-43.5$ & 26.6 & $26.8 \pm 6.5$ \\
\hline & PM & idem & $5.7-44.4$ & 27.0 & $27.0 \pm 5.8$ & idem & $10.5-46.1$ & 26.6 & $26.5 \pm 5.7$ \\
\hline & PD & idem & $6.9-50.0$ & 26.4 & $26.6 \pm 5.4$ & idem & $9.4-41.0$ & 26.8 & $25.5 \pm 5.4$ \\
\hline
\end{tabular}

PP : proximal part ; MP : median part ; DP : distal part ; $\mathbf{0 , 2}, \overline{4}$ and $\mathbf{6}$ : Storage time 
higher in proximal part than other parts (median, distal) whatever the cultivar and storage time were, whereas it was smaller in tuber distal part. Indeed, $75 \%$ of the starch granule size from "Kangba" and "Krenglè" cultivars proximal parts were lower to 41.6 $\mu \mathrm{m}$ and $41.3 \mu \mathrm{m}$ respectively at the beginning of storage (month 0) and then lower to 38.4 $\mu \mathrm{m}$ and $31.5 \mu \mathrm{m}$ respectively at the end of storage (month 6). This study revealed the existence of more and more small sized granules during the storage and this would be sustained by the increasing amylasic hydrolysis reported by Diopoh and Kamenan (1981) during the post-harvest storage.

\section{Conclusion}

The survey of the physical aspect of starch granules showed that the starch granules of the yam's different tuber parts from Dioscorea cayenensis rotundata complex did not present a morphological variability but rather the differences in distribution. The shapes in the tuber different parts were similar. The proximal part of the yam tuber had the highest size of starch granules and the smallest one in distal part, whatever the cultivar was. They all decreased during the post-harvest storage. Storage influences the starch granule size. Indeed, factors as cultivar, storage time and tuber part considerably influence the starch granules. It would be important to take into account these parameters when using the starch.

\section{REFERENCES}

Amani NG, Tetchi FA, Dufour D, Kamenan A. 2002. A comparative study of the syneresis of yam starches and other modified starches. J. Food Technol. Afr., 7 (1): 4-8.

Amani NG, Tetchi FA, Coulibaly A. 2004. Physico-chemical properties of starch from ginger rhizome (Zingiber officinale Roscoe) of Ivory Coast. Tropicultura, 22(2): 77-83.

Badenhuizen NP. 1969. The Biogenesis of Starch Granules in Higher Plants.
Appleton-Century-Crofts: New York; 1115.

Charles AL, Huang TC, Chang YH. 2008. Structural analysis and characterization of a mucopolysaccharide isolated from roots of cassava (Manihot esculenta Crantz). Food Hydrocolloids, 22: 184-191.

Cleveland WS. 1993. Visualizing Data (1st edn). Hobart Press, Summit: New Jersey, U.S.A.

Deang RM, Del Rosario RR. 1999. Physicochemical characteristics of starches from some root crops. The Phillippines Agric., 76: 176-231.

Dégras L. 1986. Yam: Tropical Tuber, Maisonneuve et Larose GP (ed), Technical and Agricultural Tropical Productions : Paris, France 36; 408.

Dégras L. 1994. Yam: Tropical Tuber, Maisonneuve et Larose GP (ed), Technical and Agricultural Tropical Productions : Paris, France; 421.

Delpeuch F, Favier JC, Charbonnière R. 1978. Characteristics of starches from tropical food plants. Ann Techn. Agric., 27: 809826.

De Vizcarrondo CA, Mariela AR, Fanny P. 2004. Characterisation of Dioscorea bulbifera native starch. Arch. Latinoam Nutr., 54(2): 241-245.

Diopoh J, Kamenan A. 1981. Distribution of amylase, phosphorylase and acid phosphatase in some dioscoréacées (Yams) in Côte d'Ivoire. Physiol. Vég., 19: 401-405.

Doumbia S, Touré M, Mahyao A. 2006. Commercialisation de l'igname en Côte d'Ivoire: Etat actuel et perspectives d'évaluation. C. E. R. F. / Agric., 15(3): 273-277.

Drogba SA, Amani NG. 2007. Morphological characteritics and crystalline structure of granules of some wild yam species (Dioscorea) from Côte d'Ivoire Forest zone. Agricult J., 2(3): 441-446.

Hoover R. 2001. Composition, molecular structure, and physicochemical properties 
of tuber and root starches: A review. Carbohydr Polym., 45: 253-267.

Gallant DJ, Bewa H, Buy QH, Bouchet B, Szylit O, Sealy L. 1982. On ultrastructural and nutritional aspects of some tropical tuber starches. Starch/Stärke, 34(8): 255-262.

Lindeboom N, Chang PR, Tyler RT. 2004. Analytical, biochemical and physicochemical aspects of starch granule size, with emphasis on small granule starches: A Review. Starch/Stärke, 56: 89-99.

Moorthy SN. 2002. Physicochemical and Functional Properties of Tropical Tuber Starches: A Review. Starch/Stärke, 54: 559-592.

Sangeetha M, Rai T. 2006. Morphology and functional properties of corn, patio and tapioca starches. Food Hydrocolloids, 20: 557-566.

Scherrer B. 1984. Biostatistic. Gäctan Morin; 850 .
Svegmark K, Hermansson AM. 1993. Microstruture and rheological properties of composite of patato starch granules and amylase: a comparison of observed and predicted structure. Food Struct., 12: 181-193.

Tetchi FA, Rolland-Sabaté A, Amani GN, Colonna P. 2007. Molecular and physicochemical characterisation of starches from yam, cocoyam, cassava, sweet potato and ginger produced in the Ivory Coast. J. Sci. Food Agric., 87: 1906-1916.

Trèche S. 1989. Nutritional potential of yam (Dioscorea Spp.) grown in Cameroon. Vol: I. text. Vol. II: Appendices. ORSTOM Edn, Collection Studies and Thesis , Paris; 595.

Wickramasinghe HAM, Takigawa S, Yamauchi H, Noda T, Matsuura-Endo C. 2009. Comparative analysis of starch properties of different root and tuber crops of Sri Lanka. Food Chem., 112: 98103. 